\title{
Development of SCAR Markers for Species Identification in the Genus Shorea (Dipterocarpaceae)
}

\author{
By H. S. Nuroniah ${ }^{1), 3)}$, O. Gailing ${ }^{2), 3)}$ and R. FinkeldeY ${ }^{3), *)}$
}

(Received 19 $9^{\text {th }}$ May 2010)

\begin{abstract}
The development of molecular markers unambiguously distinguishing groups at different taxonomic levels has numerous forensic applications. The identification of tropical timber is of particular interest in this context. We describe the development of SCAR (Sequence Characterized Amplified Region) markers for forensic applications taking the example of two closely related species of the tropical tree family Shorea (Dipterocarpaceae). Two AFLP (Amplified Fragment Length Polymorphism) fragments have been described earlier showing strong differentiation between $S$. leprosula and $S$. parvifolia. The AFLP markers were isolated from a gel, re-amplified, cloned and sequenced. Primer sets were designed from these sequences and AFLP fragments were converted into SCAR markers. The SCAR markers and PCR-RFLP markers of the chloroplast region trnLF digested with HinfI were used to screen in total 557 samples of $S$. parvifolia and $S$. leprosula from nineteen widely separated populations in Indonesia. Complete genetic differentiation between species was observed based on the putatively nuclear SCAR marker and the PCR-RFLP of the cpDNA region. We found a good agreement between leaf morphological variation and species identification based on both marker types and no indication for interspecific hybridization.
\end{abstract}

Key words: SCAR, Dipterocarpaceae, molecular identification, tropical timber, species assignment, hybridization.

\section{Introduction}

The use of DNA-based molecular markers for forensic applications depends on the isolation of DNA from different types of tissue (RACHMAYANTI et al., 2006) and the investigation of markers differentiating genotypes at various levels from individuals to species or even genera (FINKELDEY et al., 2010). AFLP (Amplified Fragment Length Polymorphism) is a fingerprinting technique that permits the analysis of a subset of restriction fragments from a complete digest of genomic DNA (Vos et al., 1995). Complex fingerprints such as AFLP fragment patterns often allow to assign genotypes to groups such as spatially isolated populations based on multilocus patterns (CAO et al., 2006). However, low quantity and high degradation of DNA from 'difficult' tissue such

1) Centre for Plantation Forest Research and Development, Gunung Batu 5, Bogor, Indonesia.

2) School of Forest Resources and Environmental Science, Michigan Technological University, 1400 Townsend Dr, Houghton, Michigan, USA.

$\left.{ }^{3}\right)$ Forest Genetics and Forest Tree Breeding, University of Göttingen, Büsgenweg 2, Göttingen, Germany.

*) Correspondence: R. Finkeldey. Tel: +49-551-393536; Fax: +49551-398367. E-Mail: rfinkel@gwdg.de as wood (De Filippis and MAGel, 1998; DumolinLAPÈGUe et al., 1999; DeGUILloux et al., 2002; RACHMAYANTI et al., 2006) precludes the direct use of the technique (MCLENACHAN et al., 2000). Furthermore, AFLP markers are too expensive and too laborious for single locus screenings (BRUGMANs et al., 2003), the reproducibility of AFLP markers is lower than for single locus markers and homoplasy of equal-sized fragments cannot be excluded (SHAN et al., 1999; VEKEMANs et al., 2002). Accordingly, the development of simple markers reliably differentiating taxonomic units at different levels is an important step towards the use of molecular tools in forensic science.

Timber identification of tree species and their origins is technically essential for monitoring and control of illegal activities in timber production and thus enforcement of species trade regulations (WINGATE and McFARLANE, 2005). Species identification by molecular tools is particularly important for closely related taxa which are difficult to differentiate by other methods. This applies in particular to a large number of tropical tree species and their timber. The development of molecular markers for species identification can be used to detect timber of protected taxa and, in case of endemic species, to broadly identify the region of origin of samples, which obviously originate from the distribution area of the identified species.

In Southeast Asian tropical lowland forests dipterocarp species dominate the forest canopy; Shorea is the largest genus of the family Dipterocarpaceae (AsHTON, 1982). S. parvifolia Dyer and S. leprosula Miq. are the most dominant trees of mixed dipterocarp forests in Indonesia (Ashton, 1982). They are abundant on deep clay soils at elevations below $700 \mathrm{~m}$ asl (NEWMAN et al., $1996 \mathrm{a}, 1996 \mathrm{~b})$. The distribution ranges of the two species widely overlap; both species occur in Peninsular Thailand, Peninsular Malaysia, Sumatra and Borneo (PRoseA, 1994). Like many other tree species of the family Dipterocarpaceae, both $S$. leprosula and S. parvifolia are large trees (up to $60 \mathrm{~m}$ high) and popular commercial timber species in Indonesia. The timber of S. leprosula and $S$. parvifolia is classified as light hardwood of the red meranti group (NEWMAN et al., 1996a, 1996b).

Five other Shorea species were included in the survey in order to allow comparisons at the species level. These species are less common than both $S$. leprosula and $S$. parvifolia and regarded as endangered (S. platyclados) or even critically endangered (all other species) according to IUCN criteria (http://www.iucnredlist.org/). Shorea acuminata is closely related to both S. leprosula and $S$. parvifolia since the three species belong to the same section Mutica of the genus (Ashton, 1982). The 
wood of $S$. acuminata is also classified as red meranti. The species is mainly found on well drained, undulating land. The wood of $S$. palembanica of section Brachypterae is also considered as light red meranti, but this species has specific habitat requirements along rivers or in freshwater swamps. S. platyclados, another species of section Brachypterae, belongs to the dark red meranti group. The species is endemic to Indonesia and occurs predominantly at higher altitudes above $700 \mathrm{~m}$ a.s.l. The wood of S. guiso (section Shorea) is classified as Balau; this lowland species is rare, but widely distributed in Southeast-Asia. S. ovalis of section Ovalis is the only polyploid species (ASHTON, 1982; INDRIOKO, 2005) included in this study.

Wood anatomical analyses can be performed to identify the Red Meranti group but not the exact species (Prosea, 1994; Martawijaya et al., 2005) except if the identification is based on electron microscopy (ABE and FUJII, 2007). Chemical fingerprinting tools based on gallic acid content have been developed but the application can be used only for the distinction of the Red Meranti group from other Meranti groups (KATO and HishIYAMA, 2007). Hardwood of the Red Meranti group is the source of world's most demanded plywood (PROSEA, 1994). However, man-caused destruction of tropical rainforests has been increasing in the past half-century, and many primary forests have been degraded by illegal logging and shifting cultivation in Indonesia and elsewhere (ScOTLAND and LUDWIG, 2002).

The genetic diversity of S. leprosula and S. parvifolia in Indonesia has been investigated by CAO et al. (2006). In total 268 samples from eight populations in Indonesia were analyzed using Amplified Fragment Length Polymorphism (AFLP) markers (Vos et al., 1995). The study reported that $S$. leprosula is genetically more vari- able than $S$. parvifolia at the population and species level. Two out of 56 AFLP markers were found to show high levels, but no complete differentiation between species. These markers can be useful as diagnostic markers to verify the species and to identify potential interspecific hybrids (Ishiyama et al., 2008) in combination with chloroplast DNA markers.

The main objective of the present study is to convert AFLP fragments showing high differentiation among species into SCAR markers useful for species identification. Specifically, we aimed to develop SCAR markers differentiating the species Shorea leprosula and $S$. parvifolia. We tested the usefulness of the developed SCAR marker for species identification by comparing results to variation at PCR-RFLPs of a polymorphic chloroplast region (INDRIOKO, 2005; INDRIOKO et al., 2006) and to leaf morphological traits for a large number of $S$. leprosula and $S$. parvifolia plants.

\section{Materials and Methods}

\section{Study site and plant material}

Samples were obtained from 19 locations from three different islands in Indonesia (Table 1). S. leprosula samples were collected from 18 populations, those of S. parvifolia were collected from 10 populations. All populations on Java Island (Haurbentes, Darmaga, Carita) are plantations established between 1940 and 1986. The other populations in Sumatra and Borneo are natural forests. Plants were collected from natural stands in an area of 100-300 ha, keeping a minimum distance of $30 \mathrm{~m}$ from each other.

We also sampled the closely related species Shorea palembanica, S. guiso and S. platyclados from Haur bentes (Java). Samples of $S$. acuminata were collected

Table 1. - Geographic location and sample size of S. leprosula and S. parvifolia populations.

\begin{tabular}{|c|c|c|c|c|c|}
\hline \multirow[t]{2}{*}{ Site } & \multirow[t]{2}{*}{ Abbreviation } & \multicolumn{2}{|c|}{ Approximate geographic location } & \multicolumn{2}{|c|}{ Sample size } \\
\hline & & Latitude & Longitude & S. leprosula & S. parvifolia \\
\hline Haurbentes Java & HJ & $6^{\circ} 10^{\prime}-6^{\circ} 35^{\prime} \mathrm{S}$ & $106^{\circ} 20^{\prime}-106^{\circ} 30^{\prime} \mathrm{E}$ & 24 & - \\
\hline Darmaga Java & DJ & $6^{\circ} 36^{\prime}-6^{\circ} 37^{\prime} \mathrm{S}$ & $106^{\circ} 32^{\prime}-106^{\circ} 33^{\prime} \mathrm{E}$ & 20 & - \\
\hline Carital Java & $\mathrm{C} 1 \mathrm{~J}$ & $6^{\circ} 45^{\prime} \mathrm{S}$ & $105^{\circ} 01^{\prime} \mathrm{E}$ & 20 & - \\
\hline Carita2 Java & $\mathrm{C} 2 \mathrm{~J}$ & $6^{\circ} 45^{\prime} \mathrm{S}$ & $105^{\circ} 01^{\prime} \mathrm{E}$ & 9 & - \\
\hline Asialog Sumatra & AS & $2^{\circ} 01^{\prime} 60^{\prime \prime} \mathrm{S}$ & $103^{\circ} 14^{\prime} 60^{\prime \prime} \mathrm{E}$ & 12 & 38 \\
\hline Pasir Mayang Sumatra & PS & $0^{\circ} 08^{\prime} \mathrm{S}$ & $103^{\circ} 20^{\prime} \mathrm{E}$ & 10 & 25 \\
\hline TN Bukit 30 Sumatra & TS & $1^{\circ} 05^{\prime}-2^{\circ} 06^{\prime} \mathrm{S}$ & $102^{\circ} 13^{\prime}-103^{\circ} 14^{\prime \prime} \mathrm{E}$ & 23 & 15 \\
\hline Nanjak Makmur Sumatra & NS & $0^{\circ} 18^{\prime} 59^{\prime \prime} \mathrm{S}$ & $101^{\circ} 50^{\prime} 27^{\prime \prime} \mathrm{E}$ & 17 & 29 \\
\hline Tebo Jambi Sumatra & $\mathrm{TjS}$ & $1^{\circ} 00^{\prime}-1^{\circ} 45^{\prime} \mathrm{S}$ & $102^{\circ} 00^{\prime}-102^{\circ} 45^{\prime} \mathrm{E}$ & 16 & - \\
\hline Tering Borneo & TB & $0^{\circ} 00^{\prime}-0^{\circ} 10^{\prime} \mathrm{N}$ & $115^{\circ} 22^{\prime}-116^{\circ} 38^{\prime} \mathrm{E}$ & 23 & - \\
\hline Sari Bumi Kusuma Borneo & $\mathrm{SB}$ & $1^{\circ} 49^{\prime} 57^{\prime \prime} \mathrm{S}$ & $112^{\circ} 51^{\prime} 32^{\prime \prime} \mathrm{E}$ & 39 & 51 \\
\hline ITCI Borneo & IB & $1^{\circ} 3147^{\prime} \mathrm{S}$ & $116^{\circ} 06^{\prime} 33^{\prime} \mathrm{E}$ & 18 & 6 \\
\hline Bukit Bangkirai Borneo & $\mathrm{BkB}$ & $0^{\circ} 14^{\prime}-1^{\circ} 15^{\prime} \mathrm{S}$ & $117^{\circ} 32^{\prime}-118^{\circ} 35^{\prime} \mathrm{E}$ & 16 & 20 \\
\hline Sumalindo Borneo & $\mathrm{SmB}$ & $1^{\circ} 12^{\prime} 13^{\prime \prime} \mathrm{N}$ & $115^{\circ} 11^{\prime} 22^{\prime}, \mathrm{E}$ & 26 & 31 \\
\hline Berau Borneo & $\mathrm{BB}$ & $2^{\circ} 30^{\prime} \mathrm{S}$ & $132^{\circ} 30^{\prime} \mathrm{E}$ & 9 & 16 \\
\hline Ketapang Borneo & $\mathrm{KB}$ & $1^{\circ} 00^{\prime}-1^{\circ} 15^{\prime} \mathrm{S}$ & $110^{\circ} 45^{\prime}-111^{\circ} 00^{\prime} \mathrm{E}$ & 10 & - \\
\hline West Kutai Borneo & $\mathrm{WkB}$ & $0^{\circ} 00^{\prime}-0^{\circ} 45^{\prime} \mathrm{S}$ & $115^{\circ} 30^{\prime}-115^{\circ} 45^{\prime} \mathrm{E}$ & 11 & - \\
\hline Muara Teweh Borneo & $\mathrm{MtB}$ & $0^{\circ} 00^{\prime}-0^{\circ} 2^{\prime} \mathrm{S}$ & $114^{\circ} 30^{\prime}-115^{\circ} 10^{\prime} \mathrm{E}$ & 6 & - \\
\hline Batu Ampar Borneo & $\mathrm{BaB}$ & $0^{\circ} 45^{\prime}-0^{\circ} 50^{\prime} \mathrm{N}$ & $116^{\circ} 48^{\prime}-117^{\circ} 00^{\prime} \mathrm{E}$ & - & 17 \\
\hline Total & & & & 309 & 248 \\
\hline
\end{tabular}


from Berau (Borneo). Samples of $S$. ovalis were collected from Pasir Mayang (Sumatra) and Berau (Borneo).

Leaves of adult trees, saplings and seedlings were sampled. Species identification in the field was done on the basis of leaf morphological characters. The leaf samples were dried and preserved in silica gel for DNA isolation. Samples from three sites in Borneo (KB, WkB, MtB) were collected as seeds and identified according to the mother trees.

\section{DNA extraction}

Total genomic DNA was extracted from dried leaf material using the DNeasy ${ }^{\circledR} 96$ Plant Kit protocol of Qiagen (Hilden, Germany) following the instructions of the manufacturer. The quality of the DNA was checked on $1 \%$ agarose gels using Tris-acetate (1x TAE) as running buffer after staining with ethidium bromide.

\section{Re-amplification and isolation of AFLP fragments}

AFLP fingerprints were generated based on the protocol described by Vos et al. (1995) with minor modifications by CAO et al. (2006). AFLP reactions were carried out with the primer pair EcoRI-ACA/MseI-GAA. The selective $E c o$ RI primer was labelled with the fluorescent dye Cy-5. The amplified fragments were separated on $7 \%$ polyacrylamide (PAA) gels. DNA was isolated from the gel and purified based on a protocol described by WEIBERG (2008). The gel was then directly scanned on a Typhoon 8600 Fluorescence Imaging System to allow careful positioning of the bands. The targeted fragments were excised from the gel using a scalpel. Gel plugs were transferred to $400 \mu \mathrm{l}$ elution buffer $(0.2 \mathrm{M} \mathrm{NaAc})$ and incubated for $10 \mathrm{~min}$ at room temperature, followed by $15 \mathrm{~min}$ at $\sim 70^{\circ} \mathrm{C}$. After incubation, the samples were centrifuged for $5 \mathrm{~min}$ at $8,000 \mathrm{rpm}$. The supernatants were transferred to a new tube, and $20 \mu$ glycogen $(10 \mathrm{mg} / \mathrm{ml}$ ) and $420 \mu \mathrm{l}$ isopropanol were added, followed by incubation for $1-2 \mathrm{~h}$ at $-60^{\circ} \mathrm{C}$ and centrifugation for $10 \mathrm{~min}$ at $12,000 \mathrm{rpm}$. The pellets were washed with ethanol and re-diluted in $10 \mu \mathrm{l}$ sterile water. Two $\mu \mathrm{l}$ of the cleaned AFLP fragment suspension were used for PCR.

To further characterize the excised fragments, a touch-down PCR using selective primers was carried out. Amplification was done in a $10 \mu \mathrm{l}$ volume containing 5 ng cleaned AFLP-DNA, 1 x HotStar Taq ${ }^{\circledR}$ master mix Kit (10 mM Tris-HCl (pH 9.0), $1.5 \mathrm{mM} \mathrm{MgCl}_{2}$, $50 \mathrm{mM} \mathrm{KCl}, 0.2 \mathrm{mM}$ each of dNTPs, $0.5 \mathrm{U}$ Taq DNA polymerase) (Qiagen) and 2.5 pmol of selective primers. The PCR profile was as follows: 1 cycle of $15 \mathrm{~min}$ at $95^{\circ} \mathrm{C}, 5$ cycles of $\left(1 \mathrm{~min}\right.$ at $94^{\circ} \mathrm{C}, 1 \mathrm{~min}$ at $58^{\circ} \mathrm{C}\left(-1^{\circ} \mathrm{C}\right.$ per cycle), $1 \mathrm{~min}$ at $\left.72^{\circ} \mathrm{C}\right), 30$ cycles of $\left(1 \mathrm{~min}\right.$ at $94^{\circ} \mathrm{C}$, $1 \mathrm{~min}$ at $54^{\circ} \mathrm{C}, 1 \mathrm{~min}$ at $72^{\circ} \mathrm{C}$ ) and $10 \mathrm{~min}$ at $72^{\circ} \mathrm{C}$.

The length of amplified products was analysed by capillary electrophoresis and compared with the original AFLP fingerprint. Fragments having the same length as the AFLP fingerprint were further characterized.

\section{Cloning and sequencing of AFLP fragments}

The fragments were re-amplified with the selective AFLP primers. Two microliter of the PCR products were analyzed on a $2 \%$ agarose gel, the rest of the PCR product was purified using the Minielute PCR purification kit (Qiagen). When possible, the sequences were obtained through direct sequencing of double stranded templates derived from PCR. Cloning was performed when the amplification resulted in more than one fragment. The PCR product was cloned into the plasmid vector pBlue Script II SK. The ligated vector fragments were transformed into Escherichia coli XL1-Blue strain bacterial cells and plated onto LB agar medium. After proliferation, PCRs were performed with the white colonies using vector primers. The PCR products received from colony PCR were checked on agarose gels and purified using the Minielute PCR purification kit (Qiagen). The cleaned PCR products were used for the sequencing reaction based on the dideoxy-mediated chain termination method (SANGER et al., 1977). Sequencing was done using the BigDye Terminator v3.1 Cycle Sequencing Kit (Applied Biosystems, Carlsbad, USA) and performed with the ABI Prism ${ }^{\circledR} 3100$ Genetic Analyser. Sequencing reactions in $10 \mu \mathrm{l}$ total volume consisted of $1 \times$ ready reaction premix (Big Dye vers. 3.1), $1 \mathrm{x}$ sequencing buffer (SB 3.1), 0.35 pmol forward or reverse primer and $10 \mathrm{ng}$ purified DNA. Sequences were analysed and edited using the computer programme Staden Package version 16.0 (STADEN, 1999; available at http://staden.sourceforge.net/). Sequence alignments were conducted in BioEdit version 7.0.9 (HALL, 1999; available at http://www.mbio.ncsu.edu/ BioEdit/BioEdit.html) using ClustalW multiple alignment (THOMPSON et al., 1994). The homology of sequences with any other sequence in the GeneBank database was done by using FASTA searches in the EMBL database (COCHRANE et al., 2008, available at http://www.ebi.ac.uk/embl/).

\section{Primer design}

The SCAR primers were designed from the AFLP sequences with the Primer3 software (ROzEN and SKALETSKY, 2000; available at http://frodo.wi.mit.edu/). The primers were tested firstly on a few samples of S. leprosula and S. parvifolia. Amplification of genomic DNA with the SCAR primers was done in a $10 \mu$ volume containing $5 \mathrm{ng}$ template DNA, 1 x HotStar Taq ${ }^{\circledR}$ master mix Kit (Qiagen) and $2.5 \mathrm{pmol}$ of each primer. The forward primer was labelled with the fluorescent dye 6FAM (blue). The PCR profile was as follows: 1 cycle of $15 \mathrm{~min}$ at $95^{\circ} \mathrm{C}, 35$ cycles of $\left(1 \mathrm{~min}\right.$ at $94^{\circ} \mathrm{C}, 45 \mathrm{sec}$ at $56^{\circ} \mathrm{C}, 1 \mathrm{~min}$ at $72^{\circ} \mathrm{C}$ ) and $10 \mathrm{~min}$ at $72^{\circ} \mathrm{C}$. Amplification products were analysed by capillary electrophoresis on the ABI Prism $3100^{\circledR}$ Genetic Analyser (Applied Biosystems). GS 500 ROX (fluorescent dye ROX) was used as an internal size standard. Length variants were recognized with the software packages GeneScan 3.7 and Genotyper 3.7 (Applied Biosystems).

\section{Chloroplast DNA analyses}

PCR-RFLP analyses were conducted based on the protocol described by INDRIOKO (2005). Amplification of genomic DNA with trnLF primers was done in a $10 \mu \mathrm{l}$ volume containing $5 \mathrm{ng}$ template DNA, 1x HotStar Taq ${ }^{\circledR}$ master mix Kit (Qiagen) and 2.5 pmol of each primer. 
The PCR profile was as follows: 1 cycle of $15 \mathrm{~min}$ at $95^{\circ} \mathrm{C}, 40$ cycles of $\left(1 \mathrm{~min}\right.$ at $94^{\circ} \mathrm{C}, 45 \mathrm{sec}$ at $55^{\circ} \mathrm{C}, 90 \mathrm{sec}$ at $72^{\circ} \mathrm{C}$ ) and $10 \mathrm{~min}$ at $72^{\circ} \mathrm{C}$. The primers $\operatorname{trn} \mathrm{LF}$ are located in the intergenic spacer between $\operatorname{trn} \mathrm{L}$ and $\operatorname{trn} \mathrm{F}$ (LF) and amplify a fragment of about $1.1 \mathrm{~kb}$ (TABERLET et al., 1991). The restriction of the amplified fragments was performed in a final volume of $7 \mu \mathrm{l}$ using $2.5 \mu \mathrm{l}$ of PCR products and 1 unit Hinf I restriction enzyme. Digestion products were resolved by electrophoresis on $2.5 \%$ agarose gels.

The procedure for the amplification of the chloroplast microsatellite ccmp6 (WEISING and GARDNER, 1999) was performed based on the protocol described by INDRIOKO (2005). Amplification of genomic DNA with ccmp6 primers was done in a $10 \mu \mathrm{l}$ volume containing $5 \mathrm{ng}$ template DNA, 1 x HotStar Taq ${ }^{\circledR}$ master mix Kit (Qiagen) and 2.5 pmol of each primer. The PCR profile was as follows: 1 cycle of $15 \mathrm{~min}$ at $95^{\circ} \mathrm{C}, 35$ cycles of $(1 \mathrm{~min}$ at $94{ }^{\circ} \mathrm{C}, 45 \mathrm{sec}$ at $50^{\circ} \mathrm{C}, 45 \mathrm{sec}$ at $72^{\circ} \mathrm{C}$ ) and $10 \mathrm{~min}$ at $72^{\circ} \mathrm{C}$. Genomic DNA was amplified using the fluorescence dyed forward primer 6-FAM for genotyping. Amplification products were run on the ABI Prism ${ }^{\circledR}$ 3100 Genetic Analyser and analysed using Genescan 3.7 and Genotyper 3.7 softwares (Applied Biosystems).

\section{Assessment of leaf morphological traits}

The assessment of leaf morphological traits was carried out based on a protocol described by KREMER et al. (2002) for oaks with modifications to adjust the method to dipterocarps for a subset of the samples analyzed with molecular markers. All leaves were measured on the following characters: leaf length (LL), petiole length (PL), leaf width (LW), wide leaf to petiole (WP), dometiana length (DL), angle between mid-vein and veinlets $(\mathrm{AV})$ and the number of veins (NV). Then three transformed variables were generated using the following formulas:

Lamina shape or obversity $(\mathrm{OB})$ : OB $=100 \times \mathrm{WP} / \mathrm{LL}$

Petiole ratio (PR):

Lobe width ratio (LWR):

$$
\mathrm{PR}=100 \mathrm{x}
$$$$
\mathrm{PL} /(\mathrm{LL}+\mathrm{PL})
$$

$$
\text { LWR = } 100 \times \mathrm{LW} / \mathrm{LL} .
$$

Based on these characters multivariate procedures were used for analyzing the data using the computer software SPSS version 12.0 for Windows.

\section{Results and Discussion}

Isolation and sequencing of the AFLP-465 and AFLP-467 fragments

Two AFLP fragments of a length of $465 \mathrm{bp}$ and $467 \mathrm{bp}$ showed strong differentiation between $S$. leprosula and $S$. parvifolia. Sequencing of these fragments revealed that the $S$. leprosula specific fragment (465 bp) and the $S$. parvifolia specific fragment $(467 \mathrm{bp})$ show a high homology to each other and to a fragment of similar size occurring in both species (469 bp). Some SNPs (Single Nucleotide Polymorphisms) were found not only between AFLP-469 and AFLP-465 or AFLP-467 but also between fragments AFLP-465 and AFLP-467. The alignment of sequences of AFLP-465, AFLP-467 and AFLP-469 showed that the homology of these 3 frag- ments is more than $84 \%$, whereas the homology between AFLP-465 fragment and AFLP-467 fragment is 96\% (Figure 1). Thus, the fragments AFLP-469 and AFLP-465 or AFLP-467 for S. leprosula and S. parvifolia, respectively, represent duplicated DNA regions. Similar duplications of AFLP markers have been reported in studies on other species (NEGI et al., 2000; MCLenACHAN et al., 2000). Both the AFLP-465 and the AFLP-467 fragments show a deletion of $3 \mathrm{bp}$ compared to the AFLP-469 fragment. A species-specific deletion of $3 \mathrm{bp}$ was found in the AFLP-465 fragment at position 86-88 (Figure 1) in S. leprosula.

FASTA3 (http://www.ebi.ac.uk/Tools/fasta33/nucleotide. html) searches of AFLP-465 sequences using the EMBL database (COCHRANE et al.. 2008) identified one close hit (E value 8.5e-08) to Dryobalanops aromatica (Dipterocarpaceae) DNA, microsatellite locus Dra428 (accession number AB271965), with 67.3\% homology for a region of $171 \mathrm{bp}$ (NANAMI et al., 2007). No homology was found between AFLP-465 sequences with any cpDNA or mtDNA sequence of any species. The fragments AFLP465 and AFLP-467 were thus predicted to be located in the nuclear genome.

The SCAR primers were designed on the basis of the sequence data obtained from the excised AFLP fragments (Figure 1). The forward primer 5'-TAAGAAGGGAGAACCCAAATTGCTG-3' was designed from the first nucleotide of genomic DNA. The reverse primer 5'ACGTCTACA TGGCAGAACCAGTG-3' was designed around the indel site, where the last three nucleotides are completely different for the AFLP-469 fragment, in order to avoid the amplification of this fragment. The primers amplified only one region resulting in products of different length in each species. The SCAR primers were tested to amplify five different species (2-3 samples/species), mostly from the red meranti group. S. leprosula showed a specific length fragment using the SCAR marker, whereas S. palembanica, S. acuminata, $S$. guiso, S. ovalis and S. platyclados showed amplification products of the same length as $S$. parvifolia. Thus, this marker can be used to discriminate between $S$. leprosula on the one hand and S. parvifolia, S. palembanica, S. acuminata, S. guiso, S. ovalis and S. platyclados on the other hand. Other markers should be used to unambiguously identify those species, which cannot be distinguished with the SCAR marker. Suitable variation in different chloroplast regions is, for example, described in INDRIOKO (2005). It should also be noted for forensic applications that most Shorea species of the red meranti group apart from the common $S$. leprosula and $S$. parvifolia, including those investigated in this study, are rare, often endangered and, accordingly, seldomly traded on international timber markets.

Even though the SCAR primer amplified a single band, some of the samples were sequenced since SCAR markers may amplify homologous regions from different chromosomes (SHAN et al., 1999). Sequencing of the SCAR markers confirmed that the target region was amplified. Four SNPs (Single Nucleotide Polymorphisms) were found between sequences of $S$. parvifolia and S. leprosula. 


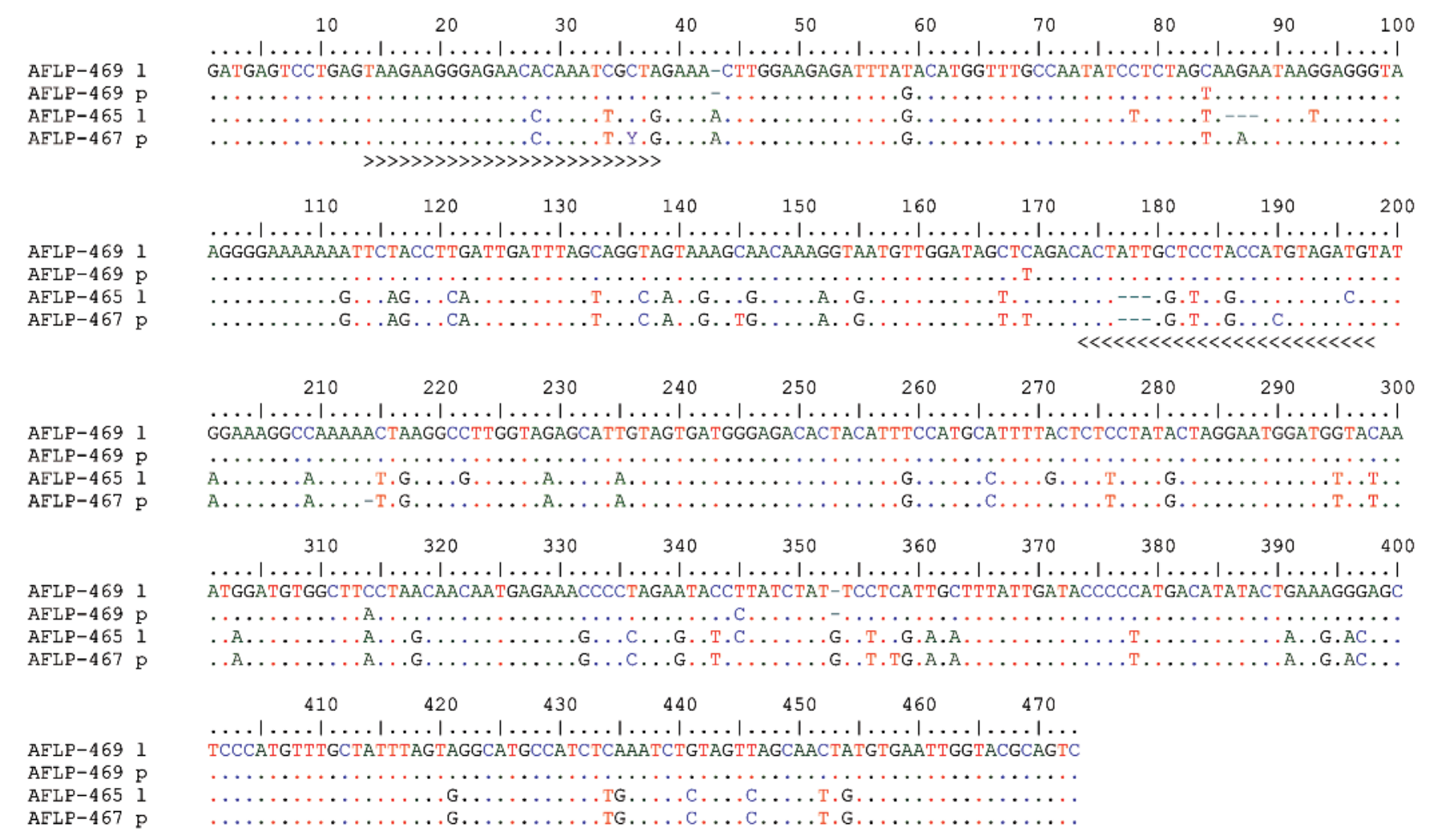

Figure 1. - Sequence alignments of AFLP-465 (1; S. leprosula), AFLP-467 (p; S. parvifolia) and AFLP-469 fragments. The forward and reverse primers for SCAR markers are shown by arrows. Dots represent the same nucleotide as in the first row. Different nucleotides show the presence of single nucleotide polymorphism (SNP). Hyphens indicate the absence of nucleotides in given sequences. $\mathrm{Y}$ means nucleotide $\mathrm{C}$ or $\mathrm{T}$.

\section{Chloroplast DNA markers}

The following chloroplast markers were analyzed: (i) the chloroplast microsatellite ccmp6 and (ii) PCR-RFLP of the trnLF region with HinfI. INDRIOKO (2005) found no variation in $S$. leprosula using ccmp6 and a specific restriction pattern of PCR-RFLP trnLF-HinfI for S. leprosula (Figure 1, pattern no 1). This pattern resulted since S. leprosula has a HinfI restriction site in the trn LF sequence which is missing in $S$. parvifolia (GAMAGE et al., 2006). INDRIOKO (2005) found variation in ccmp6 for $S$. parvifolia (2 haplotypes with one base pair difference) and a common pattern of PCR-RFLP trnLF-Hinf I for all Shorea sp. investigated except S. leprosula (cf. Fig. 2).

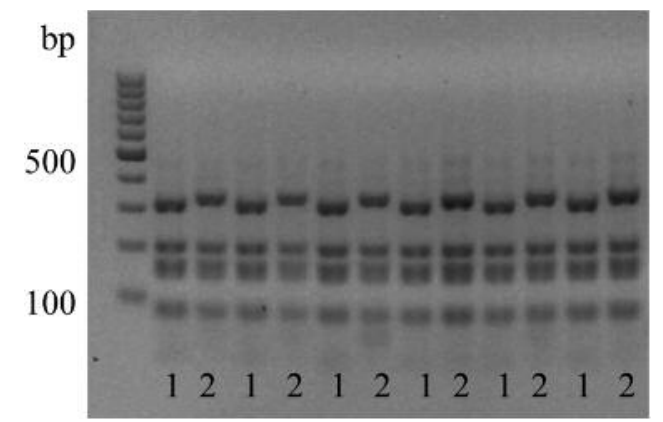

Figure 2. - PCR-RFLP patterns for S. leprosula and S. parvifolia using primer-enzyme combination trnLF-Hinf I. (1) Pattern for S. leprosula, (2) Pattern for S. parvifolia. Standard is a 100 bp size marker.

\section{Comparison between chloroplast DNA and SCAR markers}

A total of 557 samples were screened at nuclear DNA and cpDNA in $S$. parvifolia and $S$. leprosula. When the nuclear SCAR marker was compared with the PCRRFLP pattern, identical results were obtained. Based on the amplification of the SCAR marker and the restriction pattern of trnLF-HinfI 294 samples were grouped as $S$. leprosula and the other 263 as $S$. parvifolia. The complete congruence of the PCR-RFLP and the SCAR markers allowed reliable species identification resulting in a complete differentiation between species.

There is a strong, but not complete differentiation between $S$. leprosula and $S$. parvifolia at ccmp6 in species that are identified based on the other investigated markers. Most trees (290 samples) identified as S. leprosula showed a fragment length of $97 \mathrm{pb}$ at ccmp6, but four samples produced a fragment of $98 \mathrm{bp}$. The majoritiy of trees (222 samples) identified as $S$. parvifolia had the fragment $98 \mathrm{bp}$, but 41 samples ( 36 from the population SB) had the shorter fragment of 97 bp. In this population, the majority of the S. parvifolia samples $(71 \%)$ exhibited the otherwise rare fragment size. The most likely reason for these results is homoplasy at the chloroplast microsatellite region. The finding points towards the importance of large and wide screening of numerous samples to reliably identify robust species-specific markers in closely related taxonomic groups. 


\section{Leaf morphological assessment}

Ten variables were used to analyse leaves from 212 trees by principal component analysis (PCA). The species was defined by (i) morphological assessment in the field and (ii) SCAR and PCR-RFLP analyses. These ten leaf characters were then analyzed using PCA. According to the results of the PCA, there are three components with eigenvalues higher than 1, explaining $78.73 \%$ of the total variation. The first component is mainly influenced by traits expressing the size of the leaf; the second component is mainly influenced by petiole ratio and the third one is more connected to the shape of the leaf.

The results of PCA on the first two variables showed that $S$. parvifolia and $S$. leprosula can be differentiated into two major partially overlapping clusters (Figure 3). However, a number of samples which were identified as $S$. leprosula in the field fall in the $S$. parvifolia cluster (Figure 3, left). Many of these samples were identified as S. parvifolia based on SCAR and PCR-RFLP trnLFHinf I markers. If these samples are regarded as $S$. parvifolia, the taxa are better differentiated, although few samples with contrasting results according to leaf morphological and genetic analyses were observed (Figure 3, right).

Proper species identification using morphology should not only take into consideration leaf characters but also other characters including flower traits and seed morphology, which can only rarely be observed in adult tropical trees and not at all in young plants. Since most discrepancies between field assignment and genetic identification were observed for seedlings and saplings (data not shown), we conclude that species identification in the field is unreliable for these young plants. It is quite likely that phenotypic identification of seedlings/ saplings in the field is inaccurate either due to microenvironmental differences commonly observed in the field or differences in plant growth and development. The combination of two independent molecular markers is a robust tool to distinguish between species in young plants, where morphological distinction between the species $S$. leprosula and S. parvifolia is difficult.

Hybridization among Shorea species has been reported in previous studies (ASHTON, 1982; HARADA et al., 1994; ISHIYAMA et al., 2003; IsHIYAMA et al., 2008). Based on sequences of the nuclear GapC and PgiC genes ISHIYAMA et al. $(2003,2008)$ found similar or identical haplotypes and proposed the occurence of inter-specific hybridization between four Shorea species: S. acuminata, S. curtisii, S. leprosula and $S$. parvifolia. In contrary, CAO et al. (2006) found strong frequency differences in AFLP bands between species and a clear separation of $S$. leprosula and $S$. parvifolia based on the AFLP markers. In this study, we found complete congruence between a putative nuclear DNA (the SCAR marker) and chloroplast DNA (PCR-RFLP of trnLF-HinfI), allowing unambiguous species identification. Thus, this study does not support the occurrence of inter-specific hybridization between the two species.

\section{Correlation between AFLP markers and SCAR markers}

AFLP and SCAR markers show incongruence in 9 out of investigated 250 samples. In AFLP fingerprints, AFLP-465/467 fragments were not present in four samples; five samples had both fragments. Differences between AFLP profiles were due mainly to disparities in
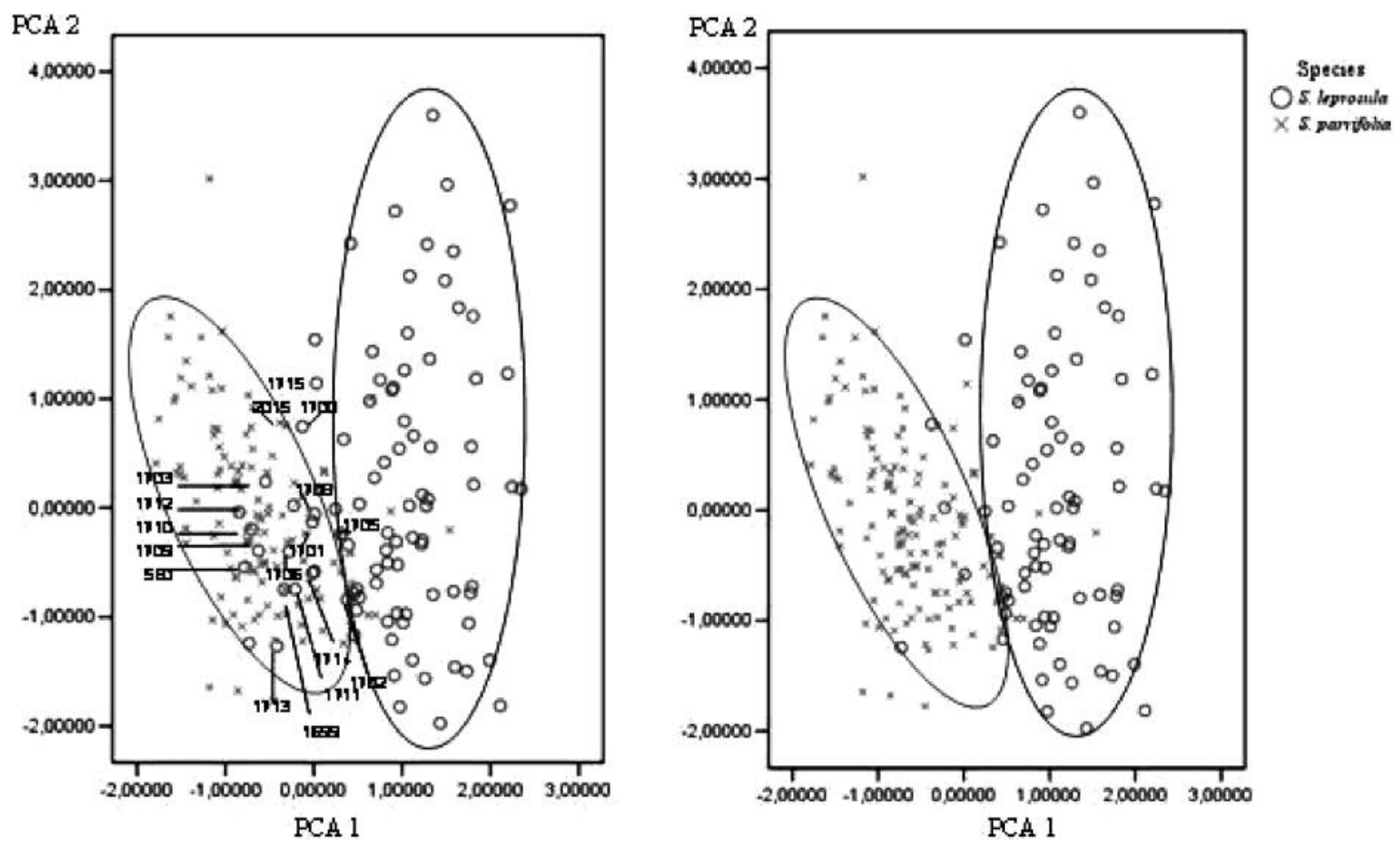

Figure 3. - Distribution of first and second synthetic variables based on principal component analysis of leaf morphological traits. Species identification based on field assessments (left), and genetic identification using the SCAR and PCR-RFLP patterns (right). 


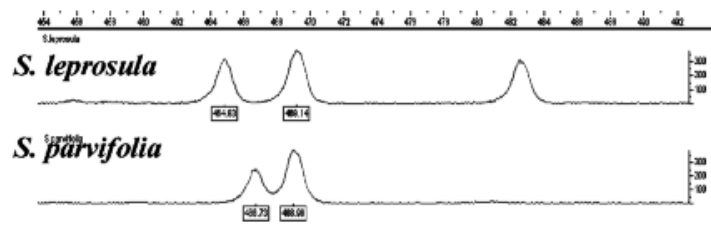

AFLP

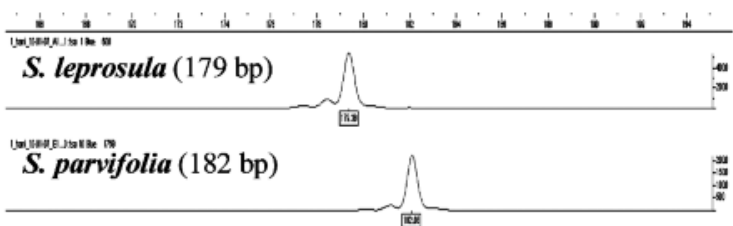

SCAR

Figure 4. - Electropherogram of the AFLP and SCAR markers for the species S. leprosula and S. parvifolia.

peak fluorescence intensities and a slight shift between two peaks (size homoplasy). Peak appearance or disappearance in AFLP fingerprints were observed especially for peaks with weak intensity (allelic drop-out). Allelic drop-out, i.e. failure to amplify an allele during PCR, may be associated with the insufficient quantity or low quality of the DNA template (TABERLET et al., 1996), but is also observed if high quality DNA is used (SOULSBURY et al., 2007). Recent studies showed that allelic drop out is typical for alleles with a longer product size (BonIN et al., 2004), as it is the case for AFLP-465 bp and AFLP $467 \mathrm{bp}$. The presence of both fragments (AFLP-465 and AFLP-467) can be caused by homoplasy, i.e. the occurrence of non- homologous fragments of the same size (SHAn et al., 1999; VeKemans et al., 2002).

All the samples that have been genotyped at AFLPs by CAO et al. (2006) were tested again with the SCAR marker. For all samples that had the AFLP-465 fragment present in the AFLP fingerprint transformation resulted in the SCAR marker of 179 bp length (Figure 4). For all samples with the presence of AFLP-467 the corresponding SCAR allele had a length of $182 \mathrm{bp}$. In nine cases, where the differentiation between the two species was not possible with the AFLP marker since either none or both fragments (AFLP-465 and AFLP467) were observed, the SCAR marker showed the allele $179 \mathrm{bp}$ and identified the same species as PCR-RFLP of cpDNA (S. leprosula). Using AFLP-465 or AFLP-467 fragments as diagnostic markers can cause errors and ambiguous results. Due to the high specificity of the SCAR marker as a single locus marker such kind of genotyping errors are not expected.

The development of markers commonly starts with sequence analysis of the candidate DNA region. For many closely related plant species, chloroplast markers were chosen to differentiate between species, for example within the genera Acer (TABERLET et al., 1991) and Abies (ZIEGENHAGEN et al., 2005). In the present study markers were developed from anonymous DNA (AFLP) and combined with the chloroplast marker to discriminate between two closely related species.

SCAR markers are generally used for different identification purposes in sample sizes of less than 100 (BRAdEen and Simon, 1998; Negi et al., 2000; SANTOS and Simon, 2002; Huaracha et al., 2004). More often, markers for species identification are tested in only a few samples per species (BEISMANN et al., 1997; IsHIYAMA et al., 2003; Kress et al., 2005; ZiEgenhAGEN et al., 2005). Testing in large samples is difficult to carry out because the most frequently used molecular technique to differentiate among species is sequencing, i.e based on sequence differences in target regions. Furthermore, material from widely separated regions as in our study is rarely available.

Preliminary tests indicated the feasibility to use the SCAR marker for species identification purposes with DNA extracted from dry dipterocarp wood. Accordingly, the method allows forensic applications and a reliable identification of the species as a first step towards the identification of the origin of timber. We used a similar approach to develop a SCAR marker distinguishing geographic regions within the natural distribution of S. leprosula (NuRoniah, 2009; Finkeldey et al., 2010; NURONIAH et al., in prep.),

Our results prove that the conversion of AFLPs to SCAR markers allows the development of robust markers for identification purposes at different taxonomic levels. These tools can subsequently be used in a forensic context. However, SCAR marker development based on the described technology is laborious and time consuming. Recently developed high-throughput sequencing technologies will allow to screen a multitude of genomic regions with limited costs and effort enabling a faster progress towards the identification of informative markers for forensic applications.

\section{Acknowledgements}

Samples were supplied by Dr. I. Z. SIREGAR, Dr. U. J. SIREGAR from Bogor Agricultural Institute, Indonesia and Dr. S. INDRIOKO, ITTO project PD 41/00 Rev 3 (F,M) from Gajahmada University, Indonesia. The leave measurements data was provided by Dr. I. Z. SIREGAR and Dr. U. J. Siregar. We thank Prof. P. Karlovsky and Dr. A. WEIBERG for their support in AFLP fragment isolation and O. DoLYNSKA for her technical assistance in the laboratory. The authors are grateful for the helpful comments of an anonymous reviewer. The first author acknowledges the generous financial support of the German Academic Exchange Service (DAAD, Bonn).

\section{References}

ABE, H. and T. FuJII (2007): Anatomical identification of wood of section Rubroshorea species, pp. 23-26. In: Proceedings of the International Symposium on Development of Improved Methods to Identify Shorea Species Wood and its Origin, edited by T. FUJI, IUFRO, Tokyo.

Ashton, P. S. (1982): Dipterocarpaceae. Flora Malesiana 9: $237-552$. 
Beismann, H., J. H. A. Barker, A. Karp and T. Speck (1997): AFLP analysis sheds light on distribution of two Salix species and their hybrid along a natural gradient. Molecular Ecology 6: 989-993.

Bonin, A., E. Bellemain, P. Bronken Eidesen, F. PomPANON, C. BRochman and P. TABERlet (2004): How to track and assess genotyping errors in population genetics studies. Molecular Ecology 13: 3261-3273.

BRADEEN, J. M. and P. W. SimON (1998): Conversion of an AFLP fragment linked to the carrot Y2 locus to a simple, codominant, PCR-based marker form. Theoretical and Applied Genetics 97: 960-967.

Brugmans, B., R. G. M. van DeR Hulst, R. G. F. Visser, P. LINDHOUT and H. J. vAN ECK (2003): A new and versatile method for the successful conversion of AFLP markers into simple single locus markers. Nucleic Acids Research 31 (10): e55. DOI: 10.1093/nar/gng055.

CaO, C. P., R. Finkeldey, I. Z. Siregar, U. J. Siregar and O. GAILING (2006): Genetic diversity within and among populations of Shorea leprosula Miq. and Shorea parvifolia Dyer (Dipterocarpaceae) in Indonesia detected by AFLPs. Tree Genetics \& Genomes 2: 225-239.

Cochrane, G., R. Akhtar, P. Aldebert, N. Althorpe, A. Baldwin, K. Bates, S. Bhattacharyya, J. Bonfield, L. Bower, P. Browne, M. Castro, T. Cox, F. Demiralp, R. Eberhardt, N. Faruque, G. Hoad, M. Jang, T. Kulikova, A. Labarga, R. Leinonen, S. Leonard, Q. Lin, R. Lopez, D. Lorenc, H. MCWilliam, G. Mukherjee, F. Nardone, S. Plaister, S. Robinson, S. Sobhany, R. Vaughan, D. Wu, W. M. Zhu, R. ApweiLER, T. Hubbard and E. Birney (2008): Priorities for nucleotide trace, sequence and annotation data capture at the Ensembl Trace Archive and the EMBL Nucleotide Sequence Database. Nucleic Acids Research 36: D5-D12.

DE FilipPIS, L. and E. MAGEL (1998): Diffrences in genomic DNA extracted from bark and from wood of different zones in Robinia trees using RAPD-PCR. Trees 12: 377-384.

Deguilloux, M. F., M. H. Pemonge and R. J. Petit (2002): Novel perspectives in wood certification and forensics: dry wood as a source of DNA. Proceedings of the Royal Society of London-Series B: Biological Sciences 269: 1039-1046.

Dumolin-Lapègue, S., M. H. Pemonge, L. Gielly, P. TABERLET and R. J. Petit (1999): Amplification of oak DNA from ancient and modern wood. Molecular Ecology 8: $2137-2140$.

Finkeldey, R., L. Leinemann and O. Gailing (2010): Molecular genetic tools to infer the origin of forest plants and wood. Applied Microbiology and Biotechnology 85: 1251-1258.

Gamage, D. T., M. P. De Silva, N. Inomata, T. Yamazaki, and A. E. SzMIDT (2006): Comprehensive molecular phylogeny of the sub-family Dipterocarpoideae. Genes and Genetic Systems 81 (1): 1-12.

HALL, T. A. (1999). BioEdit: a user-friendly biological sequence alignment editor and analysis program for Windows 95/98/NT. Nucleic Acids Symp Ser 41: 95-98.

Harada, K., A. Kinoshita, N. A. Abshukor, H. Tachida and T. YAMAZAKI (1994): Genetic variation estimated in three Shorea species by the RAPD analysis. Japanese Journal of Genetics 69: 713-718.

Huaracha, E. M., M. L. Xu, K. Gasic, E. Pauwels, A. van Den Putte, J. W. Keulemans and S. S. Korban (2004): Phenotypic reaction and genetic analysis using AFLPderived SCARs for resistance to apple scab. Journal Phytopathology 152: 260-266.
INDRIOKO, S. (2005): Chloroplast DNA variation in Indonesian Dipterocarpaceae - Phylogenetic, Taxonomic and Population Genetic Aspects. Cuvilier Verlag, Göttingen.

IndRIOKo, S., O. GaILING and R. Finkeldey (2006): Molecular phylogeny of Dipterocarpaceae in Indonesia based on chloroplast DNA. Plant Systematics and Evolution 261: 99-115.

Ishiyama, H., T. Kado, M. Iwasaki, M. Matsuoka, N. A. SHukor, A. E. SzMidT and T. YAMAZAKI (2003): Nucleotide variation in the GapC region of four species of Shorea and their putative hybrids. Tropics Vol. 13 (2): 89-99.

Ishiyama, H., N. Inomata, T. Yamazaki, N. A. Shukor and A. E. SzMidT (2008): Demographic history and interspecific hybridization of four Shorea species (Dipterocarpaceae) from Peninsular Malaysia inferred from nucleotide polymorphism in nuclear gene regions. Canadian Journal Forest Research 38: 996-1007.

KATO, A. and S. HishiYAMA (2007): Identification of red meranti based on the heartwood extractives, pp. 20-22. IN: Proceedings of the International symposium on Development of Improved Methods to identify Shorea species wood and its origin, edited by T. FUJII, IUFRO, Tokyo.

Kremer, A., J. L. Dupouey, J. D. Deans, J. Cotrell, U. Csaikl, R. Finkeldey, S. Espinel, J. Jensen, J. Kleinschmit, B. van Dam, A. Ducousso, I. Forrest, U. L. DE Heredia, A. J. Lowe, M. Tutkova, R. C. Munro, S. STEINHOFF and V. BADEAU (2002): Leaf morphological differentiation between Quercus robur and Quercus petraea is stable across western European mixed oak stands. Annals of Forest Science 59: 777-787.

Kress, W. J., K. J. Wurdack, E. A. Zimmer, L. A. Weight and D. H. JANZEN (2005): Use of barcodes to identify flowering plants. Proceedings of the National Academy of Science of the United States of America 102: 8369-8374.

Martawijaya, A., I. Kartasujana, K. KadiR and S. A. PrawirA (2005): Atlas Kayu Indonesia jilid I. Badan Penelitian dan Pengembangan Kehutanan, Bogor.

McLenachan, P. A., K. StÖCKLER, R. C. Winkworth, K. McBreen, S. Zauner and P. J. Lockhart (2000): Markers derived from amplified fragment length polymorphism gels for plant ecology and evolution studies. Molecular Ecology 9: 1899-1903.

NAMAMI, S., S. IKedA, N. TANI, B. Diway, K. HARADA, Y. Tsumura, A. IтоH and T. Yamakura (2007): Development of microsatellite markers for Dryobalanops aromatica (Dipterocarpaceae), a tropical emergent tree in Southeast Asia. Molecular Ecology Notes 7: 623-625.

NeGi, M. S., M. Devic, M. Delseny and M. LaKshmikuMARAN (2000): Identification of AFLP fragments linked to seed coat colour in Brassica juncea and conversion to a SCAR marker for rapid selection. Theoretical and Applied Genetics 101: 146-152.

Newman, M. F., P. F. Burgess and T. C. Whitmore (1996a): Manual of Dipterocarps for foresters: Borneo light hardwoods. Royal Botanic Garden Edinburgh and CIFOR, Edinburgh, UK and Bogor, Indonesia.

Newman, M. F., P. F. Burgess and T. C. Whitmore (1996b): Manual of Dipterocarps for foresters: Sumatra light hardwoods. Royal Botanic Garden Edinburgh and CIFOR, Edinburgh, UK and Bogor, Indonesia.

NURONIAH, H. S. (2009): Diagnostic markers for the identification of the tree species Shorea leprosula Miq. and $S$. parvifolia Dyer and the geographic origin of $S$. leprosula Miq. Dissertation, Göttingen University. Optimus, Göttingen, Germany. 
PROSEA (1994): Plant Resources of South-East Asia 5 (1) Timber trees: Major commercial timber. Bogor. Prosea Foundation/Pudoc-DLO.

RACHMAYANTI, Y., L. LEINEMANN, O. Gailing and R. FINKELDEY (2006): Extraction, amplification and characterization of wood DNA from Dipterocarpaceae. Plant Molecular Biology Reporter 24: 45-55.

Rozen, S. and H. J. Skaletsky (2000): Primer3 on the WWW for general users and for biologist programmers. In: Krawetz, S., Misener, S. (eds). Bioinformatics Methods and Protocols: Methods in Molecular Biology. Humana Press, Totowa, NJ, pp. 365-386.

SAnger, F., S. Nicklen and A. R. Coulson (1977): DNA sequencing with chain-terminating inhibitors. Proceedings of the National Academy of Sciences of the United States of America 74: 5463-5467.

SAntos, C. A. F. and P. W. Simon (2002): Some AFLP amplicons are highly conserved DNA sequences mapping to the same linkage groups in two F2 populations of carrot. Genetics and Molecular Biology 25 (2): 195-201.

Scotland, N. and S. Ludwig (2002): Deforestation, the timber trade and illegal logging. Paper for EC workshop on forest law enforcement, governance and trade. http://www.illegal-logging.info. Brussels. 9 pp.

Shan, X., T. K. Blake and L. E. TAlBerT (1999): Conversion of AFLP markes to sequence-specific PCR marker in barley and wheat. Theoretical and Applied Genetics 98: $1072-1078$.

Soulsbury, C. D., G. Iossa, K. J. Edwards, P. J. Baker and S. HARRIS (2007): Allelic drop-out from a high-quality DNA source. Conservation Genetics 8: 733-738.

StAdEN, R. (1999): The Staden Sequence Analysis Package. Molecular Biotechnology 5: 233-241.

TABerlet, P., L. Gielly, G. Pautou and J. Bouvet (1991): Universal primers for amplification of three non-coding regions of chloroplast DNA. Plant Molecular Biology 17: 1105-1109.
Taberlet, P., S. Griffin, B. Goossens, S. Questiau, V. Manceau, N. Escaravage, L. P. Waits and J. Bouvet (1996): Realiable genotyping of samples with very low DNA quantities using PCR. Nucleic Acids Research 24: 3189-3194.

Thompson, J. D., D. G. HigGins and T. J. Gibson (1994): Clustal-W - Improving the sensitivity of progressive multiple sequence alignment through sequence weighting, position-specific gap penalties and weight matrix choice. Nucleic Acid Research 22: 4673-4680.

Vekemans, X., T. Beauwens, M. Lemaire and I. RoldănRUIZ (2002): Data from amplified fragment length polymorphism (AFLP) markers show indication of size homoplasy and a relationship between degree of homoplasy and fragment size. Molecular Ecology 11: $139-151$.

Vos, P., R. Hogers, M. Bleeker, M. Reijans, T. van DE Lee, M. Hornes, A. Frijters, J. Pot, J. Peleman, M. KUIPER and M. ZABEAU (1995): AFLP: a new technique for DNA fingerprinting. Nucleic Acids Research 23: $4407-4414$.

WEIBERG, A. (2008): Identification of genes in the vascular pathogen Vertcillium longisporum by xylem sapmetabolites of Brassica napus using an improved genome-wide quantitative cDNA-AFLP. Dissertation, Georg-August University Goettingen.

Weising. K and R. C. Gardner (1999): A set of conserved primers for the analysis of simple sequence repeat polymorphisms in chloroplast genomes of dicotyledonous angiosperms. Genome 42: 9-19.

Wingate, K. G. and P. N. McFARLANE (2005): Chain of custody and eco-labelling of forest products: a review of the requirements of the major forest certification schemes. International Forestry Review 7 (4): 342-347.

Ziegenhagen, B., V. Kuhlenkamp, B. Fady and S. Liepelt (2005): Differentiation of groups of Mediterrenean firs (Abies spp.) using a simple molecular marker. Silvae Genetica 54 (3): 123-126.

\title{
SSR and SNP Markers for the Identification of Clones, Hybrids and Species Within the Genus Populus
}

\author{
By H. Schroeder ${ }^{1), 2)}$ and M. FladunG ${ }^{1,3)}$
}

(Received $5^{\text {th }}$ August 2010)

\begin{abstract}
Several poplar species within a section, but also between sections, are cross-compatible, thus a high

1) Johann Heinrich von Thünen Institute, Federal Research Institute for Rural Areas, Forestry and Fisheries, Institute of Forest Genetics, Sieker Landstraße 2, D-22927 Grosshansdorf, Fax: +49-4102-696200

2) HiLke Schroeder. Tel.: +49-4102-696148. E-Mail: hilke. schroeder@vti.bund.de

3) Matthias Fladung. Tel.: +49-4102-696107. E-Mail: matthias. fladung@vti.bund.de
\end{abstract}

number of interspecies-hybrids occur naturally or have been artificially produced during the last 100 years. Very often, systematically kept records on the production or vegetative propagation of poplar hybrids and/or clones have not been available to date. Hence the origin of the poplar plant material used for the generation of hybrids or clones is not quite clear in many cases, thus making the differentiation between the clones a difficult task. Therefore, genetic markers are needed to clearly identify and differentiate the species and hybrids in the genus Populus, including both identification of existing clones and the breeding of new ones. One aspect of this 